\title{
Acceptance of Dating Violence Scale: Checking its psychometric properties
}

\author{
Carlos Eduardo Pimentel - Universidade Federal da Paraíba, João Pessoa, Brasil \\ Giovanna Barroca de Moura - Universidade Estadual Vale do Acaraú, João Pessoa, Brasil \\ Jaqueline Gomes Cavalcanti - Universidade Federal da Paraíba, João Pessoa, Brasil
}

\begin{abstract}
Violence by intimate partners is a cause of concern in several countries, including Brazil. Although some instruments that measure this phenomenon have been found, the Acceptance of Couple Violence Scale (ACVS) has proven to be a brief measure with satisfactory psychometric properties. For this reason, we have sought to investigate its psychometric properties in Brazilian samples. The ACVS was subjected to two studies. Study 1 indicated a two-factor structure with satisfactory internal consistency. Study 2 showed that a three-factor structure, which is in agreement with the original study, is more plausible than one- and twofactor models, with its reliability varying from 0.61 to 0.80 . In addition, a correlation was found between the factor of female violence and social desirability, which suggests that future studies should take this variable into account. It was concluded that the ACVS is a valid and precise measure and that it may be used in future studies.

Keywords: violence by intimate partner; validity; scale.
\end{abstract}

\section{Escala de Aceitação da Violência no Namoro: Verificando suas propriedades psicométricas}

\section{Resumo}

A violência nas relações íntimas é um fator preocupante em diversos países do mundo, assim como no Brasil. Algumas medidas foram encontradas para medir esse fenômeno, mas a Escala de Aceitação da Violência no Namoro (EAVN) é uma medida curta e com boas qualidades psicométricas. Tendo isso em vista, decidiu-se conhecer seus parâmetros psicométricos em amostras brasileiras. Foram realizados dois estudos com essa medida. O Estudo 1 sugere uma estrutura bi-fatorial com bons índices de consistência interna. O Estudo 2 mostrou que a estrutura tri-fatorial de acordo com o original é mais plausível do que o modelo uni e bi-fatorial com confiabilidades variando de 0,61 a 0,80 . Ademais, o fator de violência feminina mostrou-se correlacionado com a desejabilidade social, sugerindo que pesquisas futuras levem em consideração este controle. Conclui-se que a EAVN é uma medida válida e precisa e que pode ser utilizada em pesquisas futuras.

Palavras-chave: violência pelo parceiro íntimo; validade; escala.

\section{Escala de Aceptación de Violencia en el Noviazgo: Comprobación de sus Propiedades Psicométricas}

\section{Resumen}

La violencia en las relaciones íntimas es un factor preocupante en varios países del mundo, así como también en Brasil. Algunas medidas fueron encontradas para medir este fenómeno, pero la Escala de Aceptación de Violencia en el Noviazgo (EAVN) es una medida corta y con buenas cualidades psicométricas, por lo tanto, decidimos conocer los parámetros psicométricos en muestras brasileñas. Fueran realizados dos estudios con esta medida. El primer estudio sugiere una estructura bi-factorial con buenos índices de consistencia interna. El segundo estudio mostró que la estructura tri-factorial de acuerdo con el original es más plausible que el modelo uni y bi-factorial con confiabilidad que va de $0,61-0,80$. Además, el factor de violencia femenina demostró que se correlaciona con la deseabilidad social, que sugiere que las investigaciones futuras tengan en cuenta este control. Se concluye que la EAVN es una medida válida y confiable que puede ser utilizada en investigaciones futuras.

Palabras-clave: violencia de pareja; validez; escala.

\section{Introduction}

Hurts, a little slap doesn’t hurt (Furacão 2000)

Violence by intimate partners is a phenomenon that is widely acknowledged socially and by the scientific community. Although the first studies on this phenomenon focused on married couples only, starting in the 1980s, the scope was also extended to dating relationships (Doroteia, 2013; Soares, Lopes, \& Njaine,
2013) especially in North America and less often in Europe, Latin America, Africa, and Asia (Leen et al., 2013; Murta, Santos, Martins, \& Oliveira, 2013a).

According to some authors, domestic violence starts at the stage of dating, which points to the relevance of studying the relationships between youths during this period (Gelles \& Straus, 1988; Sprecher, 1999). In addition, the interest in this subject may be attributed to two significant factors: (1) the high prevalence rates of dating violence in several countries (Straus, 2004; 
Dorotéia, 2013; Haynie et al., 2013; Oliveira, Assis, Njaine, \& Pires, 2014) and (2) the psychosocial impact of dating violence on the victims, which is considered a public health concern (Haynie et al., 2013).

Several theoretical perspectives have been applied to the understanding of dating violence, among which feminist theory, social learning theory, and attachment theory stand out (Walker, 1989).

Feminist theories (Walker, 1989; Dobash \& Dobash, 1992) consider violence to be gender-specific, with the male being the perpetrator and the female being the victim. According to these theories, dating violence is a method of legitimizing male dominance over women (Doroteia, 2013).

From a different perspective, Bandura's (1977) social learning theory understands violence as a series of acts learned by observation and imitation such that the resulting behaviors are shaped through incentives and rewards. An individual who was exposed to violence as a child tends to view violent behavior in a relationship as acceptable (Oliveira \& Sani, 2009; Gover, Park, Tomsich, \& Jennings, 2011).

Another relevant approach is attachment theory, formulated by Bowlby (1988). This theory establishes an association between the individual's primary attachment styles and his/her future relationships with partners. When an individual needs proximity to the attachment figure, he/she tends to behave in a violent manner (Allison, Bartholomew, Mayseless, \& Dutton, 2008).

In addition to the perspectives described above, the literature also calls the attention to the attitudes adopted vis-à-vis dating violence as an explanatory factor for aggressive behavior in intimate relationships (Foshee et al., 1998; Foshee, Bauman, \& Linder, 1999; Doroteia, 2013). According to classic social psychology theories, such as the theory of planned behavior, attitudes are considered to be predictors of behavior (Ajzen, 2001).

The tolerance/acceptance of violence is a predictor of violent behavior in the relational context and of the actual perpetration of violence (see Dorotéia, 2013). For example, in the stage of dating, adolescents undergo a process of development regarding attitudes about intimacy, which includes expectations concerning gender roles and experiences of forms of control. These aspects may contribute to the construal of some beliefs as standard, for example, "women should be submissive" and "violence is an expression of love", which consequently influence youths' behavior. Therefore, understanding the acceptance of dating violence as an attitude may serve to predict specific behaviors, namely, violence in dating relationships.

As a function of the lack of consensus on this construct and the difficulty of victims and other involved people in disclosing its occurrence, estimating the prevalence of violence in dating relationships is not easy (Oliveira, 2011; Moura, 2012). However, there is a consensus that the prevalence of violence in love relationships between youths is significant (Straus, 2004; Haynie et al., 2013; Oliveira et al., 2014). One study conducted with 31 samples of university students from 16 countries, including Brazil, shows that approximately $29 \%$ of the participants had physically assaulted a dating partner in the previous 12 months (Straus, 2004).

Cross-sectional studies conducted in the United States detect high rates of dating violence, in its various forms of manifestation, among adolescents (Haynie et al., 2013; Leen et al., 2013). For example, in one study conducted with 2,895 adolescents, $77 \%$ of the participants who had dated report perpetrating verbal/ emotional abuse, $32 \%$ report perpetrating physical abuse, $15 \%$ report perpetrating sexual abuse, and $6 \%$ report stalking within the context of their current relationship (Niolon et al., 2015).

High rates of violence by dating partners in the previous year are also found among Portuguese (31\%; Dorotéia, 2013) and Spanish (96.3\%; FernándezFuertes, Fuertes, 2010) youths. According to some estimates, approximately $23 \%$ of Spanish and English adolescents are victims of dating violence and 30\% physically assault their current partner (Viejo, Monks, Sánchez, \& Ortega-Ruiz, 2015).

Studies on teen dating violence in Brazil are very recent and still incipient (Aldrighi, 2004; Almeida, 2010; Nascimento \& Cordeiro, 2011; Njaine et al., 2011; Antônio, Koller, \& Hokoda, 2012; Barreira, Lima, \& Avanci, 2013; Murta et al., 2013a; Murta et al., 2013b; Soares et al., 2013; Murta et al., 2014), in contrast to the international setting, where the subject is typically known as dating violence or courtship violence. This fact notwithstanding, dating violence is often recurrent, and its rates in Brazil are very high (Aldrighi, 2004; Barreira et al., 2013; Oliveira et al., 2014). The study by Barreira et al. (2013) finds that approximately $20 \%$ of adolescents are victims of physical abuse and $82.8 \%$ are victims of psychological abuse in dating relationships. The study conducted by Oliveira et al. (2014) with 3,205 adolescents from 10 Brazilian states finds that $29.8 \%$ were victims of psychological abuse by a past dating partner. 
In addition to the aforementioned data on prevalence, some studies call attention to the various consequences of dating violence for the individuals involved, such as symptoms of depression, post-traumatic stress, alcoholism, sleep disorders, anxiety, problems of sociability, suicidal thoughts, alcohol and drug consumption, acceptance of dating violence, and high-risk sexual behaviors (Foshee, Linder, MacDougall, \& Bangdiwala, 2001; Ackard, Eisenberg, \& Neumark-Sztainer 2007; Randle \& Graham, 2011; Exner-Cortens, Eckenrode, \& Rothman, 2012).

As a function of the negative impacts and high prevalence of dating violence, the use of standardized measures to evaluate this phenomenon is essential. A review of dating violence scales indicates five main scales: (1) the Conflict Tactics Scale (CTS-1); (2) the Revised Conflict Tactics Scale (CTS2); (3) the Conflict in Adolescent Dating Relationships Inventory (CADRI); (4) the Personal and Relationships Profile (PRP); and (5) the Acceptance of Couple Violence Scale (ACVS).

The Conflict Tactics Scale (CTS) was developed by Straus (1979) and adapted to the Portuguese language by Hasselmann and Reichnheim (2003); the Brazilian version exhibits conceptual equivalence to the original scale and satisfactory psychometric properties. The CTS comprises 19 items, measures the strategies used by family members to solve possible conflicts, and indirectly detects situations of domestic violence based on the following factors: reasoning, verbal aggression, and physical aggression. Regarding the Portuguese version, the values of the internal consistency index are approximately 0.70 for the verbal aggression and physical aggression factors and $0.30-0.40$ for the reasoning factor relative to husband-to-wife, wife-to-husband, and couple relationships.

It is worth noting that the applicability of the CTS to adolescents and youths has been called into question. For this reason, Straus, Hamby, Boney-McCoy, and Sugarman (1996) developed the Revised Conflict Tactics Scale (CTS-2), in which the terms and contents targeting adults were adapted for use with adolescents and other scales assessing various forms of violence were also added. The CTS- 2 comprises 78 items that describe possible actions by both the respondent and his/her partner, and it comprises five factors; three factors investigate conflict-solving tactics based on negotiation, psychological aggression, and physical assault, and the other two factors investigate the consequences of violence on the health of the respondent and his/her partner, in addition to aspects such as sexual coercion and injury.
The CTS-2 was adapted to the Brazilian population, and the resulting version was assessed with regard to its conceptual and semantic equivalence (Moraes, Hasselmann, \& Reichnheim, 2002) and psychometric properties (Moraes \& Reichnheim, 2002). The alpha values were as follows: negotiation $(\alpha=0.80)$; psychological aggression $(\alpha=0.82)$, physical assault $(\alpha=$ $0.86)$, sexual coercion ( $\alpha=0.65)$, and injury ( $\alpha=0.65)$. These results notwithstanding, Moraes et al. (2002) call attention to the large number of items included, making the scale tiresome to complete, thus representing a limitation.

The Conflict in Adolescent Dating Relationships Inventory (CADRI) was developed by Wolfe et al. (2001). It comprises 70 items that assess perpetrated and suffered violence and that make it possible to assess the use of positive or abusive conflict-solving strategies in teen dating relationships corresponding to both the respondent's behavior (35 questions) and his/her partner's behavior (35 questions). The CADRI investigates five forms of violence: physical abuse, sexual abuse, verbal or emotional abuse, relational abuse, and threatening behavior. Some aspects of the items are as follows: physical abuse - "I threw something at her"; sexual abuse - "I touched her sexually when she didn't want me to"; emotional or verbal abuse - "I insulted her with put downs"; threatening behavior - "I destroyed or threatened to destroy something she valued"; and relational abuse - "I tried to turn her friends against her" (Wolfe et al., 2001, p.283). The Cronbach's alpha values obtained in the Portuguese sample indicated satisfactory internal consistency: the total inventory $(\alpha=0.90)$; and the dimensions corresponding to the respondent's own behavior $(\alpha=0.82)$ and the partner's behavior ( $\alpha=0.81$; Saavedra, 2010).

The Personal and Relationships Profile (PRP) assesses 22 risk factors for domestic violence, including individual and relational characteristics, in addition to questions on power and communication (Straus et al., 1999). The average alpha of the PRP subscales is 0.74 .

As can be easily observed, all of the scales described above agree that the construct is multidimensional. However, it should be observed that three out of the four scales are not exclusive to dating relationships. Additionally, although one of them is, indeed, specific to that condition, it comprises a large number of items, which may be tiresome for respondents, eventually causing them to give up. For this reason, the present study seeks to validate the Acceptance of Couple Violence Scale (ACVS) for the Brazilian reality. This instrument is noteworthy for being short, with the items comprising 
three factors, and for the fact that it seeks to directly measure the male and female respondents' perspectives on dating violence, which are not considered in any of the scales discussed above. Finally, the fact that the instrument was specifically developed for dating relationships also stands out.

The ACVS was developed by Foshee et al. (1998) and comprises 11 items distributed across three factors that represent the following: 1) male-on-female violence (e.g., Girls sometimes deserve to be hit by the boys they date); 2) female-on-male violence (e.g., Boys sometimes deserve to be hit by the girls they date; and 3) the acceptance of general dating violence (e.g., Some couples must use violence to solve their problems); the scale exhibits satisfactory internal consistency, with alpha values of $0.74,0.71$, and 0.73 for the three factors, respectively. Nevertheless, studies verifying its factor structure and internal consistency are necessary.

This paper reports two studies on the ACVS. Study 1 was exploratory in nature and sought to verify the scale structure and measurement precision. Study 2 was confirmatory in nature and sought to confirm the structure identified in Study 1 by means of confirmatory factor analysis according to the recommendations by Schumacker and Lomax (2010) and to verify the scale precision and its correlation with social desirability, inasmuch as responses to self-report scales may be influenced by this variable (Steenkamp, De Jong, \& Baumgartner, 2010).

\section{$\underline{\text { Studv } 1}$}

\section{Method}

\section{Participants}

A total of 215 students attending public and private secondary schools in Guarabira (state of Paraíba) were selected to participate in the study by means of non-probability sampling. The participants' average age was 16 years old (standard deviation $-\mathrm{SD}=1.29$ ), with the largest proportion being female $(53.5 \%)$, single $(85.1 \%)$, from the middle class $(50.2 \%)$ and attending secondary school grade two $(42.8 \%)$.

\section{Instrument}

Acceptance of Couple Violence Scale (ACVS). Developed by Foshee et al. (1998), the ACVS comprises 11 items distributed across three factors that represent 1 ) male acceptance of violence against females (items 1, 3, and 4, e.g., 4. "A girl who makes her boyfriend jealous on purpose deserves to be hit.”); 2) female acceptance of violence against males (items 5, 6 and 8, e.g., 6. "A girl angry enough to hit her boyfriend must love him very much."); and 3) the acceptance of general dating violence (items 2, 7, 9, 10, and 11, e.g., 11. "Violence between dating partners is a personal matter, and people should not interfere."). The Brazilian version is the result of a translation from English performed with the help of two bilingual investigators. This version was tested in a sample composed of 10 individuals, with five being ninth graders and five being students attending secondary school grade three, which makes it possible to confirm the version's elegance and that it was easy to understand. High scores indicate high levels and low scores indicate low levels of acceptance of dating violence. The instructions provided explain the following: "In the following task, you are required to circle the response to statements 1 through 11 that best corresponds to what you think, to your level of agreement, ranging from 1 = Strongly Disagree to 4 = Strongly Agree". The scale does not have zero or an indecision point. The questionnaire further includes an informed consent form explaining the aims of the study and describing the ethical guidelines underpinning it and a Sociodemographic Questionnaire designed to collect data on gender, age, and socioeconomic class.

Procedure

A standard procedure for data collection in social research was adopted. Two duly trained undergraduate education students at XXX University were appointed to perform the data collection. These students visited public and private secondary schools in Guarabira to schedule data collection sessions. On these occasions, they were not allowed to dispel doubts about the content of the questionnaire, but only relative to the response scale. On average, 5 minutes was sufficient to complete the questionnaire. At the end of the sessions, the interviewers thanked the students, teachers, and principals.

\section{Data Analysis}

The data were initially entered into an Excel spreadsheet and then transferred to Statistical Packeage for the Social Sciences (SPSS) 18.0. Descriptive and inferential analyses were performed, including percentage, mean, frequency, missing value analysis, principal component analysis, correlation between items, and Cronbach's alpha; all of these analyses were performed using SPSS. A parallel analysis was performed using SPSS syntax. 


\section{Results}

Because the percentage of missing values was extremely low (under 5\%), they were replaced by the mean values. The principal component analysis (PCA) of ACVS items was performed without a previous definition of the number of components to be extracted or the rotation type. The results of the Kaiser-MayerOlkin index, $\mathrm{KMO}=0.806$, and of Bartlett's sphericity test, $\chi^{2}(55)=740.481, p<0.001$, indicated that analysis could proceed. A four-factor structure was found explaining $70.904 \%$ of the variance according to the Kaiser criterion, i.e., an eigenvalue $\geq 1$. Nonetheless, the Cattel scree test plot suggested almost two factors.

To dispel any doubts regarding the factor structure, Horn's parallel analysis (PA) was performed, being selected due to its robustness. The eigenvalues resulting from PCA were 4.273, 1.427, 1.073, and 1.027, and those from PA were 1.378, 1.268, 1.183, and 1.114. These results suggest that two components should to be retained; therefore, a second PCA was performed for the extraction of two components.

This second PCA resulted in two components with an eigenvalue of 4.273 and 1.427 , which explained $51.81 \%$ of the variance. In this analysis, items 4,3 , $2,7,10,1,6,11$ and 9 saturated on the first factor, whereas items 5 and 8 saturated more strongly onto the second factor, considering a factor loading of at least 0.30 to attribute items to factors. This structure mixes items from the three theoretically expected

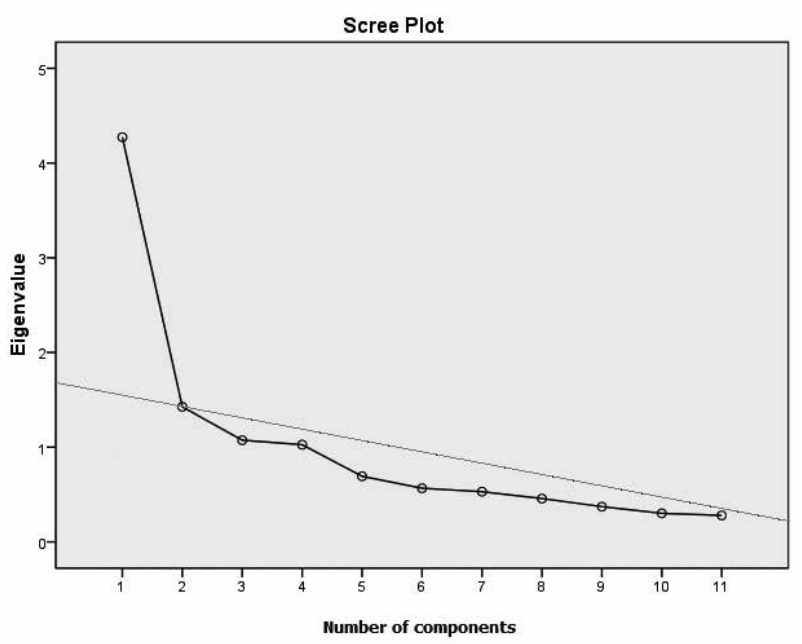

Figure 1. Scree plot of the Acceptance of Couple Violence Scale factors in the first factor, whereas only two relating to female violence are included in the second factor. On these grounds, the same analysis was performed with varimax rotation to obtain a simple structure, which is shown in Table 1.

Items 2, 10, 1, 7, 4, 3 and 9 strongly saturated on the first factor; these items correspond to general violence and male violence. Items 8,5 and 6 saturated more strongly on the second factor; these items correspond to female violence. Item 11, which corresponds to general violence, saturated equally on both factors.

To verify the precision of the scale, Cronbach's alpha was calculated with the items included in both factors, except for item 11. The first factor, with seven items, exhibited $\alpha=0.82$. The correlation between items varied from 0.23 to 0.62 , with the mean $=0.40$. The elimination of no item increased the value of $\alpha$. The second factor, with three items, exhibited $\alpha=$ 0.84 . The correlation between items varied from 0.47 to 0.93 , with the mean $=0.63$. The elimination of factor 8 leads to the increase of $\alpha$ to 0.93 . Therefore, in this particular case, there seems to be some redundancy among the items composing this subscale.

\section{Partial discussion}

In short, Study 1 did not corroborate the threefactor structure of the ACVS suggested by its original authors, with the factors being general violence, maleon-female violence, and female-on-male violence (Foshee et al., 1998). The precision indexes found were above the recommended indexes. In addition, it is not known whether the ACVS scores are affected by social desirability, which is a common occurrence when self-report scales are used. In the face of the aforementioned inconsistency and the limitation just described, Study 2 was performed.

Study 2

\section{Method}

\section{Participants}

A total of 212 students attending public and private secondary schools in Guarabira (state of Paraíba) were selected to participate in the study by means of non-probability sampling. The participants' average age was 16 years old $(\mathrm{SD}=1.19)$, with the largest proportion being female $(53.3 \%)$, single $(85.8 \%)$, from the middle class $(52.8 \%)$ and attending secondary school grade two $(42.5 \%)$. 
Table 1

Factor structure of the Acceptance of Couple Violence Scale

\begin{tabular}{|c|c|c|c|}
\hline \multirow{2}{*}{ Itens } & \multicolumn{2}{|c|}{ Fatores } & \multirow{2}{*}{$\mathbf{h}^{2}$} \\
\hline & $\mathbf{I}$ & II & \\
\hline 2. A violência entre namorados pode melhorar o relacionamento. $(\mathrm{GV})$ & 0,74 & 0,11 & 0,56 \\
\hline 10. Alguns casais devem usar a violência para resolver seus problemas. (GV) & 0,73 & 0,05 & 0,54 \\
\hline 1.Um garoto com raiva o suficiente para bater na sua namorada deve amá-la muito. (MV) & 0,71 & 0,06 & 0,50 \\
\hline 7. Há momentos que é bom haver violência no namoro. (GV) & 0,71 & 0,15 & 0,52 \\
\hline 4. Uma garota que faz ciúmes de propósito merece apanhar do namorado. (MV) & 0,63 & 0,37 & 0,54 \\
\hline 3. As garotas às vezes merecem apanhar dos seus namorados. (MV) & 0,63 & 0,32 & 0,50 \\
\hline 9. Ás vezes a violência é a única forma de expressar os sentimentos. (GV) & 0,56 & 0,13 & 0,34 \\
\hline 11. A violência entre namorados é uma escolha pessoal e ninguém deve interferir. (GV) & 0,40 & 0,40 & 0,33 \\
\hline 8. Um garoto que faz ciúmes de propósito merece apanhar de sua namorada. (FV) & 0,15 & 0,85 & 0,75 \\
\hline 5. Garotos às vezes merecem apanhar de suas namoradas. (FV) & $-0,04$ & 0,83 & 0,69 \\
\hline 6. Uma garota com raiva o suficiente para bater no seu namorado deve amá-lo muito. (FV) & 0,35 & 0,51 & 0,38 \\
\hline
\end{tabular}

Note. $\mathrm{GV}=$ general violence; $\mathrm{MV}=$ male violence; $\mathrm{FV}=$ female violence.

The instruments used were the same as those used in Study 1 (the ACVS, the Sociodemographic Questionnaire, and the informed consent form) and Stöber's (2001) Social Desirability Scale. The latter is a one-factor scale comprising 16 items with dichotomous "true" or "false" responses. Some examples of items include "1. I sometimes litter". T ( ) F ()"; and "10. When I have made a promise, I keep it - no ifs, ands or buts. T ( ) F ( )" (Stöber, 2001, p.20). This scale has proven to be correlated with Marlowe-Crowne's Social Desirability Scale $(r=0.68, p<0.001)$ and other social desirability scales (Stöber, 2001). In the present study, the value of the Kuder-Richardson Formula 20 (K-R20) was 0.62.

\section{Procedure}

The procedure was the same as that in Study 1.

\section{Data Analysis}

In addition to descriptive statistics (mean, percentage, frequency) and missing value analysis, the analysis also included estimation of Cronbach's alpha, correlation between items (considering mean values), Pearson's correlation, confirmatory factor analysis (CFA), and composite reliability; the latter were performed using AMOS version 18.0, and all others were performed with SPSS version 18.0. The $\mathrm{p}$-values in the chi-square test were calculated using the p-value from chi-square calculator. Composite reliability was calculated with the composite reliability calculator.

\section{Results}

Similar to Study 1, the percentage of missing values in Study 2 was very small (below 5\%); thus, they were replaced by the mean values. Three ACVS models were specifically tested: 1) one-factor, 2) two-factor, and 3 ) three-factor models. The goodness-of-fit indexes corresponding to the one-factor model were as follows: $\chi^{2} / d f=4.642$ (where $d f$ is the degree of freedom), AGFI $=0.77$ (where AGFI is the adjusted goodnessof-fit index), CFI $=0.71$ (where CFI is the comparative fit index), and RMSEA $=0.13$ (where RMSEA is the root mean square error of approximation) ( $90 \%$ confidence interval - $\mathrm{CI}=0.11 ; 0.15)$. The goodness-of-fit indexes corresponding to the two-factor model were as follows: $\chi^{2} / d f=3.333$, AGFI $=0.84$, CFI $=0.85$, and RMSEA $=0.11(90 \% \mathrm{CI}=0.08 ; 0.13)$. Finally, the goodness-of-fit indexes corresponding to the threefactor model were as follows: $\chi^{2} / d f=2.472$, AGFI $=$ $0.87, \mathrm{CFI}=0.89$, and RMSEA $=0.08(90 \% \mathrm{CI}=0.06$; $0.10)$. In addition to the $\chi^{2}$, the consistent Akaike information criterion (CAIC) and expected cross-validation index (ECVI) were used to compare between models; lower indexes are indicative of the best model (Byrne, 
2010). The results obtained were not the best expected results $^{1}$; however, the goodness-of-fit indexes of the three-factor model were higher and better compared to the one- and two-factor models, which was corroborated by ECVI $=0.717$ and $\chi^{2}=101.349$, i.e., the values were the lowest. Although the chi-square $\left(\Delta \chi^{2}\right)$ differences between the two- and three-factor models were not significant, as a whole, the latter exhibited better goodness-of-fit, as shown in Figure 2. All regression weights were over 0.40 and significantly different from zero, with $p<0.001$.

Additionally, the precision index of the three factors of the ACVS was calculated. The factor corresponding to general violence, comprising five items, exhibited $\alpha=0.67$ (the average correlation between items $=0.29$ ); the factor corresponding to male violence, comprising three items, exhibited $\alpha=0.61$ (the average correlation between items $=0.34$ ); and the factor corresponding to female violence, comprising three items, exhibited $\alpha=0.80$ (the average correlation between items $=0.58)$. The composite reliability $(\mathrm{CR})$ of the factors was as follows: general violence, $\mathrm{CR}=$ 0.68 ; male violence, $\mathrm{CR}=0.72$; and female violence, $\mathrm{CR}=0.74$. Pearson's correlation was applied to investigate the association of acceptance of dating violence with the social desirability total score. The only factor of acceptance of dating violence that exhibited a correlation with social desirability was female violence $(r$ $=0.20, p<0.01)$. The factors of acceptance of dating violence exhibited positive mutual correlation, with the strongest being those between male violence and general violence $(r=0.49, p<0.01)$; this finding indicates that higher scores of acceptance of male violence have a relationship with higher scores of acceptance of general violence.

Finally, the participants in Study 2 exhibited low levels of acceptance of dating violence in all three of its forms, male (mean, $M=1.36, S D=0.48$ ), female $(M=1.64, S D=0.67)$, and general violence $(M=1.37$, $S D=0.38)$.

\footnotetext{
${ }_{1}^{1}$ According to the specialized literature, higher $\chi^{2}$ values are indicative of poor goodness-of-fit; the recommended values of $\chi^{2} / \mathrm{df}$ are 2 to 3, eventually up to 5 (Byrne, 2010). Regarding the RMSEA, the suggested values should be close to 0.08 or less and, for the CFI, close to 0.95 or higher (Brown, 2006); however, $\geq 0.90$ has also already been suggested (Hu \& Bentler, 1999). In the case of the AGFI, $\geq 0.90$ may also be used; the closer to 1 the value is, the better (Byrne, 2010). In addition to the $\chi^{2}$, the CAIC and ECVI are used to compare between models; lower indexes are indicative of the best model (Byrne, 2010).
}

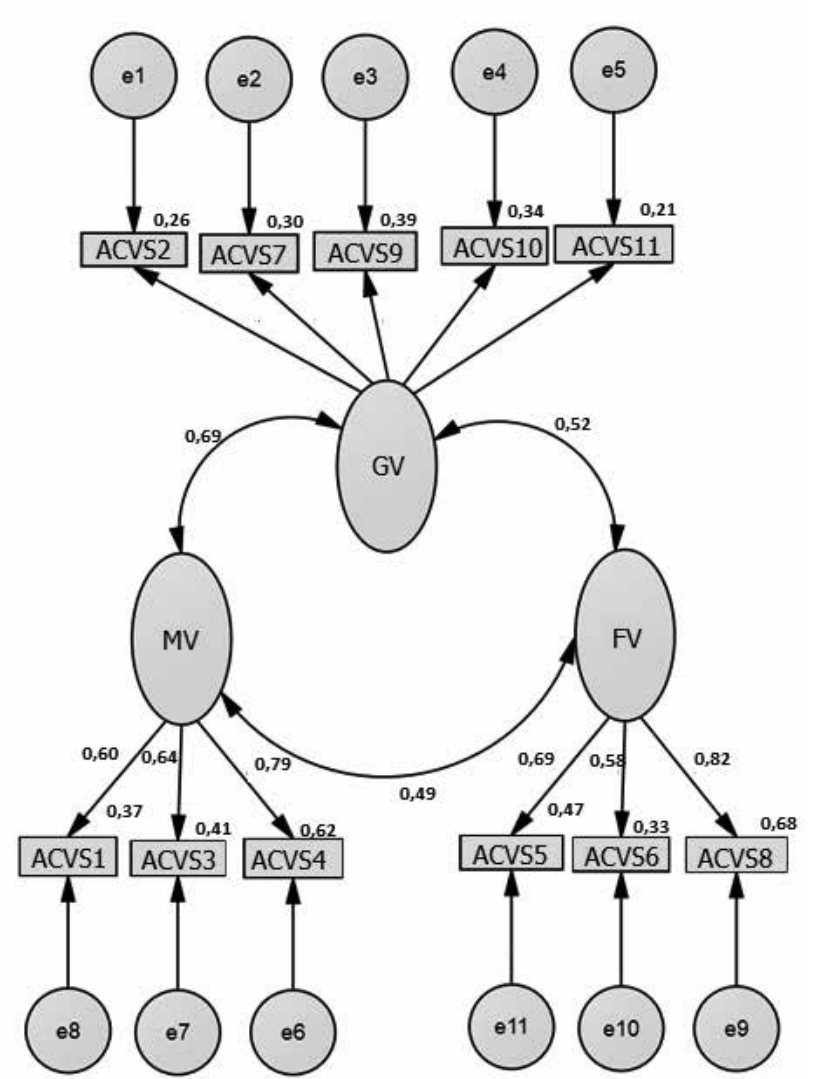

Figure 2. Three-factor model of the Acceptance of Couple Violence Scale

\section{Partial discussion}

The comparison of models by means of CFA provides empirical support to the three-factor model originally described (Foshee et al., 1998) at the expense of the one-factor model and the two-factor model suggested by PCA in Study 1. Although not excellent, satisfactory precision indexes are found. In addition, a correlation with social desirability is identified, especially in relation to the factor of female violence.

\section{Overall discussion}

The aim of the present study was to investigate the psychometric properties of the ACVS. Instead of a one-factor model or the two-factor model identified in Study 1, the three-factor model (tested in Study 2) originally suggested for acceptance of dating violence was confirmed, comprising the acceptance of violence perpetrated by males, the acceptance of violence perpetrated by females, and the acceptance of general dating 
Table 2

Goodness-of-fit indexes of ACVS tested models

\begin{tabular}{lccccccccc}
\hline Model & $\chi^{2}$ & df & $\chi^{2} / \mathrm{df}$ & AGFI & CFI & RMSEA $(90 \% \mathrm{CI})$ & CAIC & ECVI & $\Delta \chi^{2}(\mathrm{df})$ \\
\hline One- & 204.245 & 44 & 4.642 & 0.77 & 0.71 & $0.13(0.11 ; 0.15)$ & 344.09 & 1.177 & - \\
Two- & 113.333 & 34 & 3.333 & 0.84 & 0.85 & $0.11(0.08 ; 0.13)$ & 246.82 & 0.736 & $90.912(10)^{*}$ \\
Three- & 101.349 & 41 & 2.472 & 0.87 & 0.89 & $0.08(0.06 ; 0.10)$ & 260.26 & 0.717 & $11.984(7)^{* *}$ \\
\hline
\end{tabular}

${ }^{*} p<0.00001 .{ }^{* *} p>0.05$.

Table 3

Correlation between the factors of dating violence and social desirability

\begin{tabular}{lcccc}
\hline & Social Desirability & General Violence & Male Violence & Female Violence \\
\hline Social Desirability & 1 & 0.10 & 0.07 & $0.20^{* *}$ \\
General Violence & 0.10 & 1 & $0.49^{* *}$ & $0.38^{* *}$ \\
Male Violence & 0.07 & $0.49^{* *}$ & 1 & $0.37^{* *}$ \\
Female Violence & $0.20^{* *}$ & $0.38^{* *}$ & $0.37^{* *}$ & 1 \\
\hline
\end{tabular}

** $p<0.01$ (two-tailed).

violence (Foshee et al., 1998). In this regard, the ACVS seems to have construct validity, given that the factors observed correspond to the expected factors (Pacico \& Hutz, 2015).

Although the goodness-of-fitness indexes found in the CFA were not optimal (Byrne, 2010), one should bear in mind that this type of index is not static (Brown, 2006) but varies according to the model tested (Hu \& Bentler, 1999). The precision of all three ACVS factors varied from reasonable (approximately 0.60) to good (approximately 0.80) (Nunnally, 1970; Conselho Federal de Psicologia, 2003; Oviedo \& Campo-Arias, 2005; Pasquali, 2010), being very close to the values reported in the original study (Foshee et al., 1998). The same applies to the composite reliability values obtained in Study 2 (Hair, Black, Babin, Anderson, \& Tatham, 2009).

Because social desirability represents a source of response bias common to self-report scales (Steenkamp et al., 2010), the possible association of the ACVS with this variable was investigated. The results showed that the ACVS correlated with one social desirability scale (Stöber, 2001), more specifically, the ACVS factor that corresponds to female violence; this finding indicates that high scores of social desirability are accompanied by high scores of acceptance of dating violence perpetrated by females. Considering this response bias, one may suggest that future studies should use the ACVS jointly with a social desirability scale to control for the effect of the latter on acceptance of dating violence.

The availability of a Portuguese version of the ACVS is relevant because the acceptance of dating violence is a predictor of the actual perpetration of dating violence (Foshee et al., 2001), as is also indicated in classic social psychology theories, such as the theory of planned behavior (Ajzen, 2001) and Homer and Kahle's (1988) value-attitude-behavior model, which consider attitudes to be predictors of behavior.

It is thus concluded that dating violence is a multidimensional construct (Foshee et al., 1998; Wolfe et al., 2001) and that the ACVS is a brief, valid, and precise instrument that may be used in future studies seeking to measure the acceptance of dating violence.

As with any other scientific research, the present study is not free from limitations. For example, one may call attention to the nature of the sample, which was composed of secondary school students. In this regard, targeting other age ranges and education levels, such as higher education, would be relevant because these youth groups are also potential targets for dating violence. In addition, the convergent validity of the ACVS relative to other dating (Wolfe et al., 2001) or domestic (Straus et al., 1999) violence scales was not investigated; thus, it can be suggested for future studies.

Still regarding future research, an interesting approach would be, for example, to investigate the 
predictive validity of the ACVS relative to suicidal thoughts, alcohol and drug consumption, high-risk sexual behaviors, or domestic violence (Gelles \& Straus, 1988; Sprecher, 1999; Foshee et al., 2001; Ackard, Eisenberg, \& Neumark, 2007; Exner-Cortens, Eckenrode, \& Rothman, 2012). Considering the latest developments in the field of measurement (Gouveia, Athayde, Mendes, \& Freire, 2012), the development of an implicit measure of dating violence similar to the implicit-association test (IAT; Greenwald, Mcghee, \& Schwartz, 1998) would be relevant. This implicit measure could be jointly used with the ACVS, the correlation between both could be assessed, and the scales could also be compared to establish which scale is the best predictor of the perpetration of dating violence.

\section{Final Considerations}

Overall, evidence of the satisfactory validity and precision of ACVS could be obtained, making it possible to recommend the use of this scale. However, future studies should test its factor structure in other Brazilian regions, given that Study 1 did not corroborate the original model, in addition to its temporal stability in terms of test-retest, to improve the measurement of the acceptance of dating violence. It is worth emphasizing that although the precision indexes obtained were not excellent, at least they are reasonable, which should also be a topic of interest for future investigators who want a more precise measure.

Finally, in addition to contributing to the promotion of further research, adequate knowledge of the attitudes of youths in relation to the acceptance of violence by intimate partners may afford a better understanding of dating violence because it is a complex and multidimensional phenomenon. Moreover, it may contribute to the prevention of the actual perpetration of dating violence, given that according to the literature, attitudes are predictors of behavior.

\section{References}

Ackard, D. M., Eisenberg, M. E., \& Neumark-Sztainer, D. (2007). Long-term impact of adolescent dating violence on the behavioral and psychological health of male and female youth. The Journal of Pediatrics, 151(5), 476-481. http://dx.doi.org/10.1016/j. jpeds.2007.04.034

Ajzen, I. (2001). Nature and operations of attitudes. Annual Review of Psychology, 52(1), 27-58.
Aldrighi, T. (2004). Prevalência e cronicidade da violência física no namoro entre jovens universitários do Estado de São Paulo-Brasil. Psicologia: Teoria e Prática, 6(1), 105-120. Accessed October 152015 at: http://pepsic.bvsalud.org/pdf/ptp/v6n1/ v6n1a09.pdf

Allison, C. J., Bartholomew, K., Mayseless, O., \& Dutton, D. G. (2008). Love as a battlefield: Attachment and relationship dynamics in couples identified for male partner violence. Journal of Family Issues, 29, 125150. http://dx.doi.10.1177/0192513X07306980

Almeida, A. M. L. G. (2010). Prevalência da vitimizaçãa física e fatores associados à violência entre namorados adolescentes da cidade de Recife, 2008. Dissertação de Mestrado, Centro de Pesquisas Aggeu Magalhães, Fundação Oswaldo Cruz, Recife. Accessed October 152015 at: http://www.dominiopublico.gov.br/pesquisa/DetalheObraForm. do?select_action $=\&$ co_obra $=190750$

Antônio, T., Koller, S. H., \& Hokoda, A. (2012). Peer influences on the dating aggression process among Brazilian street youth: a brief report. Journal of Interpersonal Violence, 27(8), 1579-1592. http:/ / dx.doi. 10.1177/0886260511425794

Bandura, A. (1977). Social learning theory. Englewood Cliffs, NJ: Prentice-Hall.

Barreira, A. K., Lima, M. L. C., \& Avanci, J. Q. (2013). Co-ocorrência de violência física e psicológica entre adolescentes namorados do Recife, Brasil: Prevalência e fatores associados. Ciência \& Saúde Coletiva, 18(1), 233-243. http://dx.doi.org/10.1590/ S1413-81232013000100024

Bowlby, J. (1988). Cuidados maternos e saúde mental. São Paulo: Martins Fontes

Brown, T. A. (2006). Confirmatory factor analysis for applied research. New York: Guilford Press.

Byrne, B. M. (2010). Structural equation modeling with Amos: Basic concepts, applications, and programming. New York: Routledge.

Conselho Federal de Psicologia (2003). Resolução CPF $\mathrm{N}^{\circ}$ 002/2003. Acccessed: July 13 2010. Available at: http://www.pol.org.br/pol/export/sites/ default/pol/legislacao/legislacaoDocumentos/resolucao2003_02.pdf

Dobash, R. W., \& Dobash, R. P. (1992). Women, violence, and social change. New York: Routledge. 
Doroteia, J. M. R. (2013). Violência no namoro: Atitudes legitimadoras e exposição ao conflito interparental. Dissertação de Mestrado. Instituto Superior de Ciências da Saúde Egas Moniz, Monte de Caparica. Accessed October 152015 at: http://biblioteca.universia.net/html_bura/ficha/params/ title/viol\%C3\%AAncia-namoro-atitudes-legitimadoras-exposi $\% \mathrm{C} 3 \% \mathrm{~A} 7 \% \mathrm{C} 3 \% \mathrm{~A} 3 \mathrm{O}-\mathrm{ao}-\mathrm{conflito}-$ -interparental/id/58482412.html

Exner-Cortens, D., Eckenrode, J., \& Rothman, E. (2013). Longitudinal associations between teen dating violence victimization and adverse health outcomes. Pediatrics, 131(1), 71-78. http://dx.doi. org/10.1542/peds.2012-1029

Fernández-Fuertes, A. A. \& Fuertes, A. (2010). Physical and psychological aggression in dating relationships of Spanish adolescents: motives and consequence. Child Abuse Neglect, 34(3), 183-191. http://dx.doi.org/10.1016/j.chiabu.2010.01.002

Foshee, V. A., Bauman, K. E., Arriaga, X. B., Helms, R. W., Koch, G. G., \& Linder, G. F. (1998). An evaluation of Safe Dates, an adolescent dating violence prevention program. American Journal of Public Health, 88(1), 45-50. http://dx.doi.org/10.2105/ AJPH.88.1.45

Foshee, V. A., Bauman, K. E. \& Linder, G. F. (1999). Family violence and th perpetration of adolescent dating violence: Examining social learning and social control processes. Journal of Marriage and the Family, 61(2), 331-342. ISSN:0022-2445. http:// dx.doi.org/10.2307/353752

Foshee, V., Linder, F., MacDougall, J., and Bangdiwala, S. (2001). Gender differences in the longitudinal predictors of adolescent dating violence. Preventive Medicine, 32, 128 - 141. http://dx.doi.org/10.1006/ pmed.2000.0793

Gelles, R. J., \& Straus, M. A. (1988). Intimate violence. New York: Touchstone.

Gouveia, V. V., Athayde, R. A. A., Mendes, L. A. C., \& Freire, S. E. A. (2012). Introdução às medidas implícitas: Conceitos, técnicas e introdução. Revista da Sociedade de Psicologia do Rio Grande do Sul, 12(1), 80-92. Accessed October 152015 at: http://www. sprgs.org.br/diaphora/ojs/index.php/diaphora/ article/view/50

Gover, A. R., Park, M., Tomsich, E. A. \& Jennings, W. G. (2011). Dating violence perpetration and victimization among South Korean college students: A Focus on Gender and Childhood Maltreatment. Journal of Interpersonal Violence, 26(6) 1232-1263. http://dx.doi.org/10.1177/0886260510368161

Greenwald, A. G., Mcghee, D. E., \& Schwartz, J. K. L. (1998). Measuring individual differences in implicit cognition: The implicit association Test. Journal of Personality and Social Psychology, 74, 1464-1480. http://dx.doi.org/10.1037/0022-3514.74.6.1464

Hair, Jr., J. F., Black, W. C., Babin, B. J., Anderson, R. E., \& Tatham, R. L. (2009). Multivariate data analysis. Upper Saddle River, NJ: Pearson Prentice Hall.

Hasselmann, M. H., \& Reichenheim, M. E. (2003). Adaptação transcultural da versão em português da Conflict Tactics Scales Form R (CTS-1), usada para aferir violência no casal: Equivalências semântica e de mensuração. Cadernos de Saúde Pública, 19(4), 1083-1093. http://dx.doi.org/10.1590/ S0102-311X2003000400030

Haynie, D. L., Farhat, T., Brooks-Russell, A., Wang, J., Barbieri, B., \& Iannotti, R. J. (2013). Dating violence perpetration and victimization among US adolescents: Prevalence, patterns, and associations with health complaints and substance use. Journal of Adolescent Health, 53(2), 194-201. http://dx.doi. org/10.1016/j.jadohealth.2013.02.008

Homer, P. M. \& Kahle, L. R. (1988). A structural equation test of the value-attitude-behavior hierarchy. Journal of Personality and Social Psychology, 54(4), 638-646. http://dx.doi.org/10.1037/0022-3514.54.4.638

Hu, L-T., \& Bentler, P. M. (1999). Cutoff criteria for fit indexes in covariance structure analysis: Conventional criteria versus new alternatives. Structural Equation Modeling, 6, 1-55. http://dx.doi. org/10.1080/10705519909540118

Leen, E., Sorbring, E., Mawer, M., Holdsworth, E., Helsing, B., \& Bowen, E. (2013). Prevalence, dynamic risk factors and the efficacy of primary interventions for adolescent dating violence: An international review. Aggression and Violent Behavior, 18(1), 159- 174. http://dx.doi.org/10.1016/j. avb.2012.11.015

Moraes, C. L., \& Reichencheim, M. E. (2002). Cross-cultural measurement equivalence of the Revised Conflict Tactic Scales (CTS2): Portuguese version used to identify violence with couples. Cadernos 
de Saúde Pública, 18(3), 783-796. http://dx.doi. org/10.1590/S0102-311X2002000300027

Moraes, C. L., Hasselmann, M. H., \& Reichenheim, M. E. (2002). Adaptação transcultural para o português do instrumento "Revised Conflict Tactics Scales (CTS2)" utilizado para identificar violência entre casais. Cadernos de Saúde Pública, 18(1), 163-76. http:/ / dx.doi.org/10.1590/S0102-311X2002000100017

Moura, G. A. (2012). Violência no namoro e estilos parentais na adolescência: Compreensão das atitudes face à violência nas relações de namoro em adolescentes e a relação com a sua percepção dos estilos parentais. Dissertação de Mestrado. Instituto Universitário, Lisboa. Accessed October 152015 at: http://repositorio.ispa.pt/ handle/10400.12/2280

Murta, S. G., Santos, B. R. P., Martins, C. P. S., \& Oliveira, B. (2013a). Prevenção primária à violência no namoro: Uma revisão de literatura. Contextos Clínicos, 6(2), 117-131. http://dx.doi.org/10.4013/ ctc.2013.62.05

Murta, S. G., Santos, B. R. P., Nobre, L. A., Araújo, I. F., Miranda, A. A. V., Rodrigues, Í. O. \& Franco, C. T. P. (2013b). Prevenção à violencia no namoro e promoção de habilidades de vida em adolescentes. Revista de Psicologia da USP, 24(2), 263-288. http:// dx.doi.org/10.1590/S0103-65642013000200005

Murta, S. G., Ramos, C. E. P. L., Tavares, T. N. G., Cangussú, E. D. A., \& Costa, M. S. F. (2014). Desenvolvimento de um website para prevenção à violência no namoro, abandono de relações íntimas abusivas e apoio aos pares. Contextos Clinicos, 7(2), 118-132. http://dx.doi.org/10.4013/ ctc. 2014.72 .01

Nascimento, F. S., \& Cordeiro, R. D. L. M. (2011). Violência n namoro para jovens moradores de Recife. Psicologia \& Sociedade, 23(3), 516-525. http:/ /dx.doi. org/10.1590/S0102-71822011000300009

Niolon, P. H., Vivolo-Kantor, A. M., Latzman, N. E., Valle, L. A., Kuoh, H., Burton, T. M. P .H., Taylor, B. G. \& Tharp, A. T. (2015). Prevalence of teen dating violence and co-occurring risk factors among middle school youth in high-risk urban communities. Journal of Adolescent Health, 56(2), S5-S13. http://dx.doi.org/10.1016/j. jadohealth.2014.07.019

Njaine, K., Oliveira, Q. B., Ribeiro, F. M., Minayo, M. C. D. S., \& Bodstein, R. (2011). Prevenção da violência nas relações afetivo-sexuais. In Minayo M. C. S, Assis S. G., Njaine K. (Orgs.). Amor e violência: um paradoxo das relações de namoro e do'ficar'entre jovens brasileiros (p. 183-205). Rio de Janeiro: Fiocruz.

Nunnally, J. C. (1970). Introduction to psychological measurement. New York: McGraw-Hill Book Company.

Oliveira, M., Sani, A. (2009). A intergeracionalidade da violência nas relações de namoro. Revista da Faculdade de Ciências Humanas e Sociais, 6, 162-170. Porto: Edições Universidade Fernando Pessoa. Accessed February 42016 at: http://bdigital.ufp. pt/bitstream/10284/1325/1/162-170_FCHS066.pdf

Oliveira, J. A. (2011). Violência no namoro: Adaptação de um programa de prevenção em jovens universitárias. Dissertação de Mestrado. Universidade da Beira Interior, Covilhã, Portugal. Accessed October 152015 at: https://ubithesis.ubi.pt/bitstream/10400.6/2728/1/ disserta $\% \mathrm{C} 3 \% \mathrm{~A} 7 \% \mathrm{C} 3 \% \mathrm{~A} 3$ o.pdf

Oliveira, Q. B. M., Assis, S. G., Njaine, K., \& Pires, T. O. (2014). Namoro na adolescência no Brasil: Circularidade da violência psicológica nos diferentes contextos relacionais. Ciência \& Saúde Coletiva, 19(3), 707-718. http://dx.doi. org/10.1590/1413-81232014193.19052013

Oviedo, H.C \& Campo-Árias, A. (2005). Aproximación al uso del coeficiente alfa de Cronbach. Revista Colombiana de Psiquiatría, 34(4), 527-580. Accessed October 152015 at:

Pacico, J.C. \& Hutz, C.S. (2015). Validade. In C.S.Hutz, D.R.Bandeira \& C.M.Trentini (Orgs.), Psicometria (pp. 71-84). Porto Alegre: ArtMed.

Pasquali, L. (2010). Instrumentação psicológica: Fundamentos e práticas. Porto Alegre: ArtMed.

Randle, A. A., \& Graham, C. A. (2011). A review of the evidence on the effects of intimate partner violence on men. Psychology of Men \& Masculinity, 12(2), 97. http://dx.doi.org/10.1037/a0021944

Saavedra, R. (2010). Prevenir antes de remediar: Prevenção da Violência nos Relacionamentos intimos Juvenis. Tese de Doutoramento, Universidade do Minho, Portugal. Accessed October 152015 at: http://repositorium.sdum.uminho.pt/handle/1822/14248

Schumacker, R. E., \& Lomax, R. G. (2010). A beginner's guide to structural equation modeling. New York: Routledge. 
Soares, J. S. F., Lopes, M. J. M. \& Njaine, K. (2013). Violência nos relacionamentos afetivo-sexuais entre adolescentes de Porto Alegre, Rio Grande do Sul, Brasil: Busca de ajuda. Cad. Saúde Pública, 29(6), 1121-1130. http://dx.doi.org/10.1590/ S0102-311X2013000600009

Sprecher, S. (1999). "I love you more today than yesterday": Romantic partners' perceptions of changes in love and related affect over time. Journal of Personality and Social Psychology, 76, 46-53. Accessed October 152015 at: http://isites.harvard.edu/ fs/docs/icb.topic1214378.files/March\%2011\%20 Readings/Sprecher\%201999.pdf

Steenkamp, J-B.E.M., De Jong, M., Baumgartner, H. (2010). Socially desirable response tendencies in survey research. Journal of Marketing Research, XLVII (April), 199-214. http://dx.doi.org/10.1509/ jmkr.47.2.199

Stöber, J. (2001). The Social Desirability Scale-17 (SDS17): Convergent validity, discriminant validity, and relationship with age. European Journal of Psychological Assessment, 17, 222-232. Accessed October 15 2015 at: https://kar.kent.ac.uk/4466/

Straus, M. A. (1979). Measuring intrafamily conflict and violence. The Conflict Tactics (CT) Scales. Journal of Marriage and the Family, 41(1), 75-88. Accessed October 152015 at: http://www.jstor.org/ stable/351733?seq=1\#page_scan_tab_contents

Straus, M. A. (2004). Prevalence of violence against dating partners by male and female university students worldwide. Violence Against Women, 10(7), 790-811. http://dx.doi.org/10.1177/1077801204265552

Straus, M. A., Hamby, S. L., Boney-McCoy, S., \& Sugarman, D. B. (1996). The revised conflict tactics scales (CTS2) development and preliminary psychometric data. Journal of Family Issues, 17(3), 283-316. http://dx.doi.org/10.1177/019251396017003001

Straus, M. A., Hamby, S. L., Boney-McCoy, S., \& Sugarman, D. (1999). Manual for the personal and relationships profile. Durham, NH: University of New Hampshire, Family Research Laboratory.

Viejo, C., Monks, C. P., Sánchez, V., \& Ortega-Ruiz, R. (2015). Physical dating violence in Spain and the United Kingdom and the importance of relationship quality. Journal of Interpersonal Violence, 1-23. http://dx.doi.org/10.1177/0886260514567963

Walker, L. E. (1989). Psychology and violence against women. American Psychologist, 44(4), 695-702. http://dx.doi.org/10.1037/0003-066X.44.4.695

Wolfe, D., Scott, K., Reitzel-Jaffe, D., Grasley, C., \& Straatman, A.-L. (2001). Development and validation of the Conflict in Adolescent Relationships Inventory. Psychological Assessment, 13(2), 277-293. http://dx.doi.org/10.1037/1040-3590.13.2.277

Recebido em: 22/10/2015

$1^{a}$ reformulação: 27/01/2016

$2^{\mathrm{a}}$ reformulação: 06/02/2016

Aceito em: 16/06/2016 
Sobre os autores:

Carlos Eduardo Pimentel possui Doutorado em Psicologia Social, do Trabalho e das Organizações pela UnB. Atualmente é Professor Adjunto II do Departamento de Psicologia e da Pós-Graduação em Psicologia Social da UFPB. Publicou 46 artigos científicos em revistas indexadas, sendo a maioria de psicologia. Organizou 3 livros sobre psicologia social e publicou 9 capítulos. Concedeu entrevistas para a TV, rádio e jornal impresso.

E-mail: carlosepimentel@bol.com.br

Giovanna Barroca de Moura possui mestrado em Cooperación al Desarrollo pela Universidade de Valência, especialização em Saúde Mental, bacharelado em Pedagogia, licenciatura em Psicologia e formação em Psicologia. Atualmente é professora de pedagogia da Universidade Estadual Vale do Acaraú, professora substituta da Universidade Estadual da Paraiba e orientadora da UFPB Virtual do curso de Pedagogia.

E-mail: giovannabm@hotmail.com

Jaqueline Gomes Cavalcanti é Mestre em Psicologia Social pela Universidade Federal da Paraíba. Possui graduação em Psicologia pela mesma universidade.

E-mail: gomes.jaqueline@gmail.com

Contato com os autores:

Carlos Eduardo Pimentel

Rua Eduardo Medeiros, N. 125, Castelo Branco I

João Pessoa-PB, Brasil

CEP: 58050-080

Telefones: (83) 3244-2115 / (83) 98797-2085 